\title{
NOTE
}

\section{Predation on jellyfish by the cephalopod Argonauta argo}

\author{
Thomas Heeger, Uwe Piatkowski, Heino Möller
}

Institut für Meereskunde, Düsternbrooker Weg 20, W-2300 Kiel 1, Germany

\begin{abstract}
An association of Argonauta argo Linnaeus 1758 with Phyllorhiza punctata von Lendenfeld 1884 was observed in situ and collected north of Bohol Island in the Philippine archipelago. The argonaut held the exumbrella of the live jellyfish with its lateral and ventral arms. About half of the medusa bell surface was damaged and large pieces of mesogloea were lacking. The affected exumbrella area was characterized by the presence of masses of rod-like bacteria which did not occur on the undamaged ciliated surface. The center of the bell showed 2 holes interpretated as bite marks from the cephalopod. Five channels led from the holes to the medusa's gastric cavity. This connection possibly enabled the argonaut to feed on the tissue and to access particles caught by the secondary mouth papillae of the oral arms of $P$. punctata. Furthermore, the association could serve $A$. argo as protection or camouflage against predators because of the stinging capability of the scyphomedusa.
\end{abstract}

Argonauta argo Linnaeus 1758 is a pelagic octopod that occurs worldwide in tropical and warm temperate seas (Roper et al. 1984). It lives near the surface of the open ocean and swims by jet propulsion using its siphon. Only occasionally it has been reported from coastal waters. Among the 6 known species of the monotypic family Argonautidae, A. argo is the largest. Females attain a maximum size of nearly $30 \mathrm{~cm}$ shell diameter

As in most argonauts, sexual dimorphism in adult Argonauta argo is very marked. Males only reach centimeter size. Females secrete a fragile laterally compressed shell which locally serves as an important shellcraft item among Filipino natives. Other than their morphology, knowledge of the biology of argonauts is fragmentary, and almost nothing is known about their natural diet.

Very few reports describe the feeding behaviour of female Argonauta argo (de Lacaze-Duthiers 1892, Young 1960, von Boletzky 1983). They are restricted to 1 or 2 wk studies on animals captured in coastal waters and kept in aquaria. During these observations, feeding was induced by bringing pieces of dead fish or shrimp into contact with the extended web of the first arms. This web is thin, flattened, and very sensitive to food stimuli (Voss \& Williamson 1971, Nixon \& Dilly 1977). It provides a specialized feeding mechanism similar to that of cirrate octopods. Active attacks to seize prey, as reported for cuttlefish and squids, have never been observed for argonauts.

According to Nesis (1977), the natural diet of female argonauts consists mainly of heteropods and pteropods. Robson (1932) described Argonauta spp. preying upon small fish and crustaceans. The symbiosis of juvenile argonauts with salps may also provide a food source for the cephalopod (Banas et al. 1982). In the present study, we report a previously undescribed association of $A$. argo with a scyphomedusa that suggests an active attack by the cephalopod.

Methods and results. During an expedition to the Philippine archipelago, an association of a female argonaut with a scyphozoan medusa was observed on 29 January 1992 while scuba diving to collect scyphozoan jellyfish. The connected animals were slowly swimming near the surface at the Middle Pass of the Danajon Bank, north of Bohol Island (position $10^{\circ} 19.5^{\prime}$ $\mathrm{N}, 124^{\circ} 15.4^{\prime} \mathrm{E}$; Fig. 1). The water depth was $489 \mathrm{~m}$; the water surface temperature was $26.8^{\circ} \mathrm{C}$.

The argonaut was identified as a female Argonauta argo. Its shell length was $96 \mathrm{~mm}$. The scyphozoan was identified as Phyllorhiza punctata von Lendenfeld 1884 and had a bell diameter of $92 \mathrm{~mm}$. During an observation period of ca $1 \mathrm{~h}$, the association was documented by underwater photography (Fig 2a). Thereafter the specimens were collected with a hand net and transferred to a 30 l glass aquarium. The argonaut then released ink and left the medusa. After identification and shell measurement, the argonaut was released alive to its natural habitat. In spite of considerable tissue damage from the cephalopod attack, the jellyfish continued to pulsate at 50 contractions $\mathrm{min}^{-1}$.

Small pieces $(5 \times 5 \mathrm{~mm})$ were removed from both damaged and unaffected exumbrella surfaces of the 


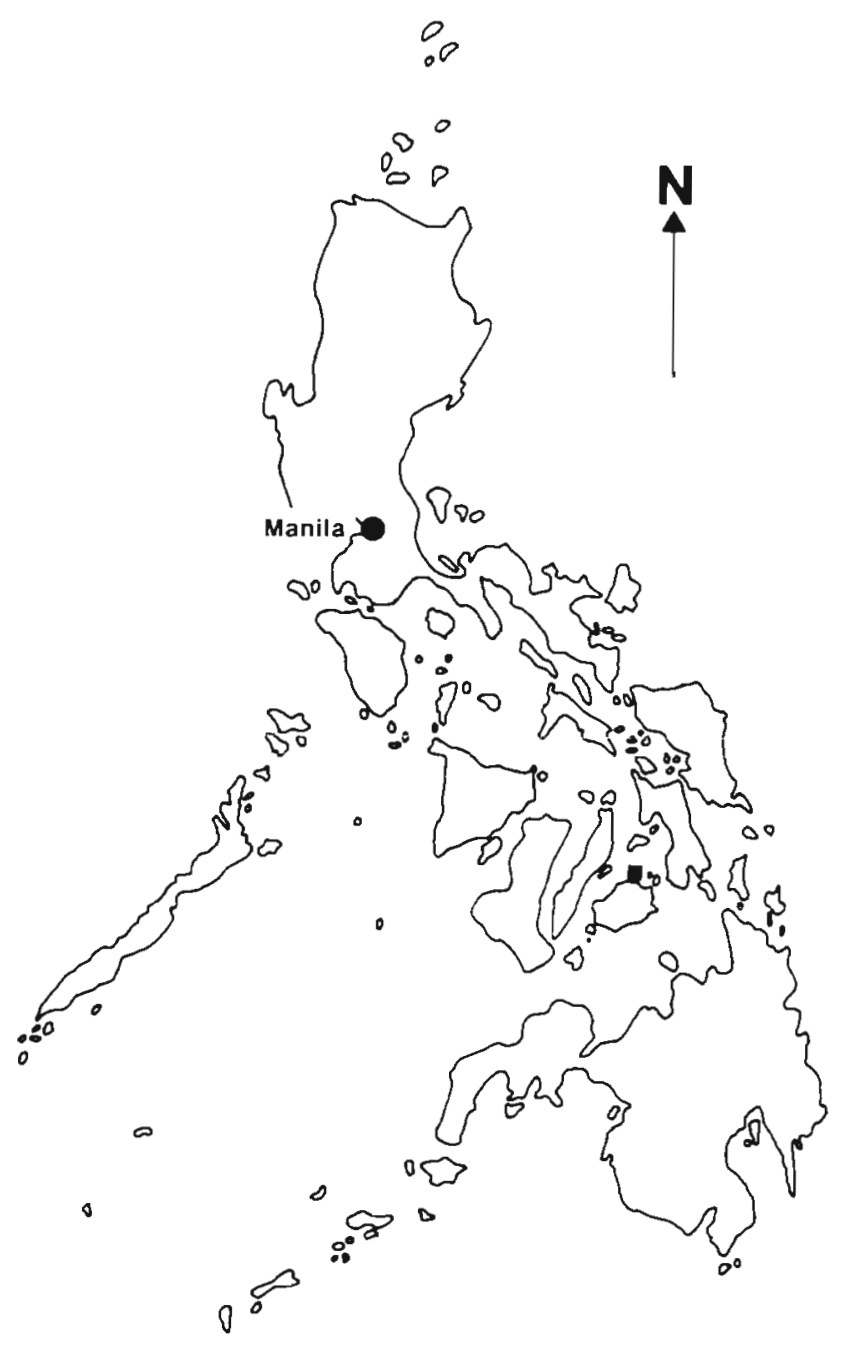

Fig. 1 Sampling site ( $\square$ ) in the Philippine archipelago

jellyfish and from its bell center, which showed bite marks of the argonaut. The tissues were fixed in $2.5 \%$ glutardialdehyde/seawater solution, dehydrated in a graded ethanol series, critical point dried with $\mathrm{CO}_{2}$ and sputtered with gold palladium. These samples were examined with a Zeiss DSM 940 scanning electron microscope (SEM). The jellyfish was preserved in $4 \%$ buffered formaldehyde/seawater solution

Close examination of the specimens demonstrated that the argonaut had seized the jellyfish with its lateral and ventral arms holding the exumbrella tightly with its suckers (Fig 2a). The exumbrella of the jellyfish had been conspicuously damaged by this attack (Fig. 2b, c). Approximately one-half of the exumbrella surface was disrupted and large pieces of mesogloea were lacking. Two distinct holes $(20 \times 10 \mathrm{~mm}$ and $5 \times 2 \mathrm{~mm})$ with blue margins were located in the center of the bell surface (Fig. 2c). They are interpreted as bite marks of the powerful horny mandibles of the cephalopod. From these bite marks 5 channels led through the mesogloea to the gastral cavity (Fig. 2b). The cephalopod had probably used these channels to suck in particles from the gastral cavity.

The undamaged exumbrella surface was characterized by microvilli and numerous 10 to $20 \mu \mathrm{m}$ long cilia (Fig. 2d). In contrast, the bell surface connected to the cephalopod showed destroyed cell fragments without cilia and lacked the ectodermal cell layer (Fig. 2e). The entire damaged surface was covered with 1.2 to 1.6 $\mu \mathrm{m}$ long rod-like bacteria. Their highest density was found on the margin of the bite holes (Fig. 2f).

Discussion. Jellyfish are not considered to be important prey items in the marine food web, despite their high abundance and biomass values (Möller 1984). This can be explained by their water content of more than $98 \%$ and their low levels of protein, lipid and carbohydrate (Larson 1986, Arai et al. 1989, Clarke et al. 1992). There are some remarkable exceptions, however, where predation on jellyfish has been reported (Purcell 1991). The spider and blue crabs have been observed to feed on or invade Aurelia aurita (Jachowski 1963), Chrysaora quinquecirrha (Phillips et al. 1960) and Cyanea capillata (Farr 1978). Den Hartog (1980) identified scyphozoan tissue in the stomach of 2 sea turtle species. In the North and Baltic Seas mackerel have been observed removing eggs or amphipods from Aurelia aurita (Möller 1984).

Due to their slow mobility, jellyfish are easy prey. However, as the entire body surface is covered with venom-containing stinging cells, predators may be discouraged. We attached juvenile cuttlefish and young catfish Plotosus lineatus from Palau, Micronesia, to the oral arms and exumbrella of the scyphomedusa Cassiopea ndrosia and counted the number of penetrated nematocysts on the surface of the animals using SEM techniques. Only a few nematocysts were discharged on the mantle of the cuttlefish compared to the skin of

Fig. 2. Argonauta argo associated with Phyllorhiza punctata. In situ and microphotographs. (a) Cephalopod connected with its lateral and ventral arms to exumbrella of the jellyfish. Scale bar $=2.5 \mathrm{~cm}$. (b) Jellyfish exumbrella with 2 central bite marks and 5 blue channels (arrows) leading to the gastral cavity. Scale bar $=2 \mathrm{~cm}$. (c) Jellyfish exumbrella with details of 2 bite marks and blue margins. Scale bar $=1 \mathrm{~cm}$. (d to f) Scanning electron micrographs (SEM) of undamaged and damaged $P$. punctata bell surface. (d) Undamaged exumbrella covered with cilia. Scale bar $=20 \mu \mathrm{m}$. (e) Overview of damaged exumbrella with cell fragments covered with rod-like bacteria. Scale bar $=50 \mu \mathrm{m}$. (f) Close up of a bite hole margin with high density of bacteria. Scale bar $=2 \mu \mathrm{m}$ 

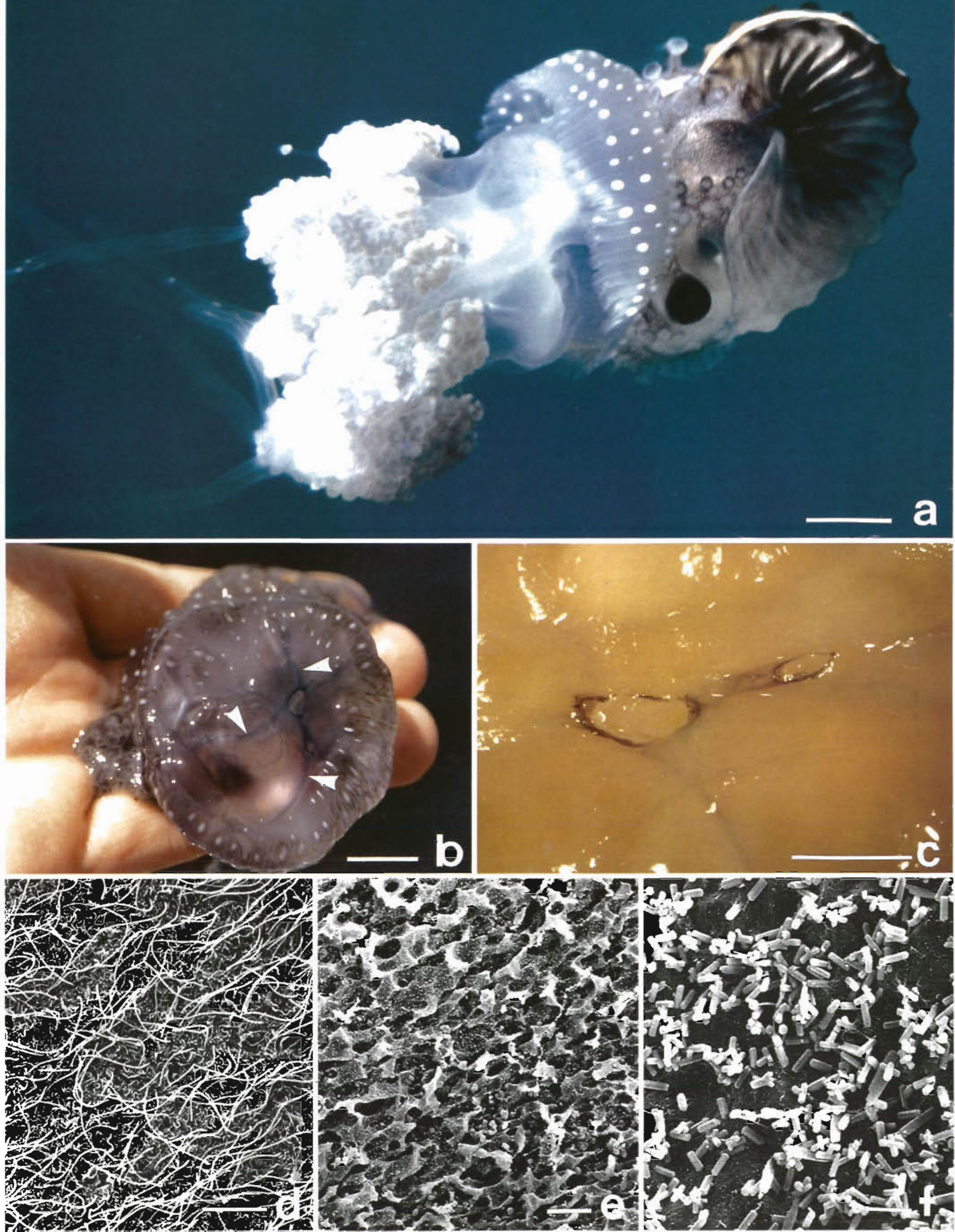
$P$. lineatus. This observation indicates that the mantle of the cuttlefish, in contrast to the skin of fish, is not an important carrier of stimulating substances for the trigger mechanism of nematocyts (Heeger \& Moller unpubl.). Therefore, it seems likely that the argonaut seized the jellyfish in order to prey directly on it, as suggested by the extensive tissue damage on the bell surface,

The formation of channels within the mesogloea of the jellyfish (Fig. 2b) is of special importance. We conclude that the argonaut produced them by consuming parts of the exumbrella and mesogloea to connect to the gastral cavity of the medusa. This would enable the cephalopod to consume zooplankton from the gastrovascular system of the jellyfish via these channels while adhering to the exumbrella. Thereby the argonaut would use the efficient secondary mouth papillae of the oral arms of the jellyfish to collect prey items for itself.

Banas et al. (1982) observed juvenile argonauts inside the branchial cavity of salp chains. Although many zooplankton organisms were in association with the salp chains, the argonauts had neither fed on them nor had they damaged the salp tissue which the authors documented by examination of gut contents. Banas et al. concluded that this association provided flotation, transportation or camouflage to the argonauts.

Besides the predator theory we suggest that the advantage of shelter or camouflage is a reasonable explanation for the medusa-argonaut association we observed. Since scyphozoans are an unattractive prey for predators like tunas, dolphinfish and swordfish (Roper et al. 1984, Bello 1991), associating with scyphomedusa could serve as protection or camouflage for argonauts.

Acknowledgements. The authors are grateful to the Deutsche Forschungsgemeinschaft (DFG) for supporting this study.

\section{LITERATURE CITED}

Arai, M. N., Ford, J. A., Wayne, J. N. C. (1989). Biochemical composition of fed and starved Aequorea victoria (Mur-

This note was submitted to the editor doch et Shearer, 1902) (Hydromedusae). J. exp. mar. Biol. Ecol. 127: 289-299

Banas, P. T., Smith, D. E., Biggs, D. C. (1982). An association between a pelagic octopod, Argonauta sp. Linnaeus 1758, and aggregate salps. Fish. Bull. U.S. 80: 648-650

Bello, G. (1991). Role of cephalopods in the diet of the swordfish Xiphias gladius, from the Eastem Mediterranean Sea. Bull. mar. Sci. 49: 312-324

Clarke, A., Holmes, L. J., Gore, D. J. (1992). Proximate and elemental composition of gelatinous zooplankton from the Southern Ocean. J. exp. mar. Biol. Ecol. 155: 55-68

de Lacaze-Duthiers, H. (1892). Observation d'un Argonaute de la Méditerranée. Archs. Zool. exp. gén. 10: 37-56

den Hartog, J. C. (1980). Notes on the food of sea turtles: Eretmochelys imbricata (Linnaeus) and Dermochelys coriacea (Linnaeus). Neth. J, Zool. 30: 595-610

Farr, J. A. (1978). Blue crab predation on jellyfish. Fla Scient. 41: $217-219$

Jachowski, R. (1963). Observations on the moon-jelly, Aurelia aurita, and the spider crab, Libinia dubia. Chesapeake Sci. 4: 195

Larson, R. J. (1986). Water content, organic content, and carbon and nitrogen composition of medusae from the Northeast Pacific. J. exp. mar. Biol. Ecol. 99: 107-120

Möller, H. (1984). Daten zur Biologie der Quallen und Jungfische in der Kieler Bucht. Möller, Kiel

Ncsis, K. (1977). The biology of paper nautiluses, Argonauta boettgeri and $A$. hians, in the Western Pacific and the seas of the East Indian Archipelago. Zool. Zh. 56: 1004-1014

Nixon, M., Dilly, P. N. (1977). Sucker surfaces and prey capture. Symp. zool. Soc. Lond. 38: 447-511

Phillips, J. H., Burke, W. D., Keener, E. J. (1960). Observation on the trophic significance of jellyfish in Mississippi Sound with quantitative data on the association behaviour of small fishes with medusae. Trans. Am. Fish. Soc. 98 $703-712$

Purcell, J. E. (1991). A review of cnidarians and ctenophores feeding on competitors in the plankton. Hydrobiologia 216/217: 335-342

Robson, G. C. (1932). A monograph of the recent Cephalopoda. Part II The Octopoda. British Museum, London

Roper, C. F. E., Sweeney, M. J., Nauen, C. E. (1984). FAO species catalogue. Vol. III. Cephalopods of the world. An annotated and illustrated catalogue of species of interest to fisheries. F.A.O. Fish. Synopses 125: 1-277

von Boletzky, (1983). Laboratory observations on a female Argonauta argo (Mollusca: Cephalopoda). Rapp. P.-v. Réun. Commn int. Explor scient. Mer Méditerr. 28: 289-290

Voss, G. L., Williamson, G. R. (1971). Cephalopods of Hong Kong. Government Press, Hong Kong

Young, J. Z. (1960). Observations on Argonauta and especially its method of feeding. Proc. zool. Soc. Lond. 133: 471-479

Manuscript first received: June 16, 1992

Revised version accepted: October 2, 1992 